\title{
Role of First Line Manager: Strategic Leadership in Implementing Successful PMS
}

\author{
Farhana Firoz $^{1}$ \& Muhammad Faisol Chowdhury ${ }^{2}$
}

${ }^{1}$ Senior Lecturer, School of Business, North South University, Dhaka, BANGLADESH

${ }^{2}$ Senior Lecturer of HRM, School of Business, North South University, Dhaka, BANGLADESH

\begin{abstract}
The paper studies the role of first line managers as strategic leaders in Bangladesh ensuring successful implementation of efficient performance management system (PMS), in high performance work systems (HPWS). In this paper, importance of PMS in HPWS has been discussed briefly with the light of previously done scholarly works. Then the paper draws attention on Bangladesh's perspective of first line managers' role as strategic leaders in major telecommunication companies, (which are considered as HPWS) in implementing PMS. To do this, quantitative data from handful of major telecommunication companies operating in Bangladesh have been collected and the whole concept has been explained with aid of a model.
\end{abstract}

Keywords: Strategic Leader; High Performance Work Systems; Performance Management System; Telecommunication Companies

JEL Classification Code: M120

\section{INTRODUCTION}

B angladesh one of the poorest countries in Asia where the concept of application of leadership role in business still needs empirical studies. Many studies on leadership practices in the context of organisational governance and Human Resource Management (HRM) can be found on western countries' perspective; very little work have been done so far on leadership issues in view of Bangladesh. Research conducted earlier on MNCs and HPWSs in Bangladesh by Zafour (2009), Mahmood (2010), Haque \& Hossain (2010) although nicely analysed the managerial leadership of the organisations of different employment sectors, there was a gap of linking the role of first line managers in achieving organisational success through performance management system (PMS).

This study thus tries to focus on how the role of strategic leadership among first line managers helps to improve implementing performance management practices in the telecom sector of Bangladesh. Today, Bangladesh is pursuing a liberal market economy. Regulatory controls and constraints have been reduced. The government has steadily achieved reduction in non-tariff restrictions on trade, rationalisation of tariff rates, improvements in export incentives, introduction of value-added-tax (VAT) and rationalisation in the import tariff and domestic tax structure. This liberalisation has encouraged increased participation of the foreign direct investment (FDI) in medium and large scale industries, specially in the telecom sector. Telecom sector has been the dominant player in the occupational industries in the current decade. This is one of the booming industries in Bangladesh with possible new dimensions in management and leadership practices. Several international telecom companies like Telenor,
Orascom, Airtel, SingTel have entered into the economy though wholly owned FDI, where a few of them have set up successful joint ventures with domestic partners. Telecom sector organisations are considered as highperformance work systems (HPWS) in Bangladesh, as they have successfully executed the 'best-in-class' PMS through strategic leadership development (Chowdhury 2011). Although ensuring effective PMS in alignment with organisational strategic leadership development is not a new phenomenon in HPWSs in Bangladesh, it has received less attention in domestic local 'bleak house' organisations (Chowdhury 2011).

As mentioned earlier, there is now overwhelming collection of literature on strategic leadership practices by first line managers in context of developed nations, very meagre to none studies have been done on the importance of first line managers implementing successful PMS though the use of AMO theory of performance, which on the colloquial level has been around for a long time. The AMO model states that performance is a function of employee ability, motivation, and opportunity, which is represented using mathematical notation as: $\mathrm{P}=\mathrm{f}(\mathrm{A}, \mathrm{M}, \mathrm{O})$. In high performance work systems (HPWS), people perform well when: 1, they are able to do so (Ability - employees possessing necessary knowledge and skills); 2 . they have the motivation to do so (Motivation - employees are willing to perform and are adequately incentivised); 3. their work environment provides the necessary support and avenues for expression (Opportunity - elimination of organisational inadequacy) (Boxall \& Purcell 2003; Ichniowski, Kochan, Levine, Olson \& Strauss 1996; MacDuffie 1995). This model has a universal relevance in workplaces. Aca- 
demically, this model can be found in the works of Dreher \& Dougherty (2002), Appelbaum, Bailey, Berg \& Kalleberg (2000), Campbell, McCloy, Oppler \& Sage(1993). Basically, the logic is that, HPWS practices such as selective hiring, extensive training, performance appraisal and feedback may develop employee knowledge and skills and thereby the collective human capital of the firm, which in turn is expected to influence firm performance positively (Lepak, Liao, Chung \& Harden, 2006; Ostroff \& Bowen, 2000). This paper therefore seeks to address the following question:

1. How does the strategic leadership role of first line managers in telecom sector organisations in Bangladesh ensure the successful implementation of performance management system?

2. How strategic leaders through the practice of AMO theory of performances are ensuring effective PMS in HPWS?

\section{Theoretical Model \& Literature ReVieW}

\subsection{Theoretical Model}

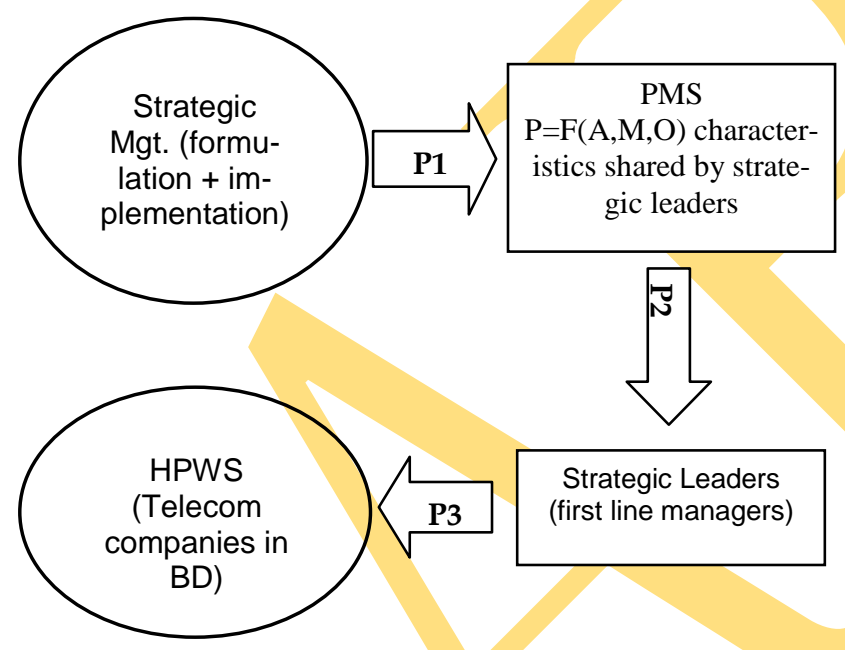

Figure 1: Propositions (P1, P2, P3) that depict the relationship of strategic management with HPWS through the development of strategic leaders who practice PMS by AMO theory.

\subsection{Literature Review}

A plethora of research exists examining the relationship of first line managers as strategic leader in successfully implementing PMS in HPWSs. Such research has been conducted at the corporate (Huselid 1995), business unit (Write, Gardner \& Moynihan 2003), and department level. In this body of concept, three basic themes emerge to link the relationship of first line managers (as strategic leaders) with PMS. First, strategic management is defined as the set of decisions and actions that result in the formulation, implementation and control of plans that helps to achieve an organisation's vision, mission, strategy and strategic objectives within the business environment in which it operates (Pearce \& Robinson 2007:3). Strategy implemen- tation is an inseparable component of the strategic management process and is viewed as the process that turns the formulated strategy into a series of actions and then results to ensure that the vision, mission, strategy and strategic objectives of the organisation are successfully achieved as planned (Thompson \& Strickland 2003:365). In more than past two decades, most of the academicians and business organisations have given importance to strategy formulation. However, strategy formulation is important but more important is its implementation. This reasoning is depicted in figure 1 as propositions 1 (P1). Second, strategy formulation is a part of strategic plan but plan is of no importance unless it is put into practice; and for this, need of strategic leaders are extremely important because of their characteristics. Strategic leadership, is described by many as one of the key drivers of effective strategy implementation (Lynch 1997; Ulrich, Zenger \& Smallwood 1999; Collins 2001; Bossidy \& Charan 2002; Thompson \& Strickland 2003; Freedman \& Tregoe 2003; Kaplan \& Norton 2004; Hrebiniak 2005; Pearce \& Robinson 2007). Moreover, in a study on South African organisations, Jooste \& Fourie (2009) found that strategic leadership positively contributes to effective strategy implementation. Many work has been done proving the fact that lack of strategic leadership can be a barrier in strategy implementation (Alexander 1985:91-97; Beer \& Eisenstat 2000: 29; Kaplan \& Norton 2004:277; Hrebiniak 2005:17), as also represented in figure 1 as propositions 1 (P1) and 2 (P2). But, scholarly work are very few in recognising the role of first line managers in implementation of strategy and thus enhancing PMS through creating HPWS. Raising the notion of implementation, strategic HRM scholars have argued that the reality of HPWS as applied on the shop floor may not always match up to the formal set of high-performance work policies designed by top and HR management (Gratton, Hope-Hailey, Stiles \& Truss 1999; Khilji \& Wang, 2006; Kinnie, Hutchinson, Purcell, Rayton \& Swart 2005; McGovern, Gratton, Hope-Hailey, Stiles \& Truss 1997; Purcell \& Hutchinson, 2007; Wright \& Nishii 2006). The realisation that there may be a gap between "intended" HRM policies and "actual" HRM practices (Wright \& Nishii 2006, p. 11) has led strategic HRM scholars to emphasize the need to investigate the role that firstline managers play in the implementation of HPWS (Purcell \& Hutchinson, 2007). This paper tries to work on this gap. General evidence of first-line involvement in HRM work is plentiful. Devolution studies have shown that first-line managers are usually involved in different areas of HPWS (e.g., Hall \&Torrington, 1998; Renwick, 2003). For instance, scholars have reported on the pivotal role that direct supervisors play in PMS, as they are charged with setting performance objectives, undertaking the performance appraisal, and giving performance feedback (den Hartog, Boselie \& Paauwe, 2004). With regard to employee training and development, researches have shown that direct supervisors are involved in identifying training needs, deciding who should be trained and creating a 
supportive environment for training transfer (Heraty \& Morley 1995; Noe, 2007). Furthermore, important responsibilities with regard to internal career progression and career development are vested with direct supervisors. Because of their frequent interaction with employees, direct supervisors can stay in touch with employee development and career aspirations and have an accurate perception of employee performance and potential in light of internal promotions (Gutteridge, Leibowitz \& Shore, 1993). Also, direct supervisors are central to employee participation, as they are the primary representatives of the organization to whom employees can voice and express their ideas, suggestions and concerns (Detert \& Burris, 2007). In short, first-line managers have been identified as important contributors to HRM operations (Hutchinson \& Purcell 2003; Hutchinson \& Purcell 2010; Purcell \& Hutchinson 2007).

Finally, PMS is a tool used by organisations to guide performance behaviour in alignment of the organisation's strategy. Organisations that have successfully implemented PMS are deriving significant benefits including productivity improvements, organisational improvements and enhanced strategic capabilities. As highlighted in figure 1 , proposition $3(\mathrm{P} £)$, leadership capabilities to ensure long-term success in meeting organisational strategic objectives rests with the leadership ability to manage PMS in accordance with organisation's needs (Gilmore \& Williams 2011; Mellow 2011; Elmuti, Minnis \& Abebe 2005; Morgan \& Rao 2002; Morrison 2000). Research based on twelve case study organisations including Tesco, Jaguar, Nationwide Building Society, Royal Mint and Siemens Medical, conducted by Purcell, Kinnie, Hutchinson, Rayton, \& Swart (2003), highlighted the relationship of strategic leadership with organisational PMS system through the introduction of 'high-performance work practices (HPWPs). These HR strategies and strategic leadership practices are applied in combination or as a 'bundle' of policies and practices, providing an integrated approach that is dependent on the operational context. Furthermore, a study of HPWPs in 2004, based on a case study of ten organisations and a survey of 294 companies in the U.K., identified specific HPWPs being employed in a number of business sector (Sung \& Ashton 2005). The study concluded that the level of HPWP adoption is linked to organisational performance, and that HPWSs employ a higher level of HPWPs through the use of strategic leadership practices than other organisations. Researches conducted by Armstrong \& Baron (2005), Ulrich \& Brockbank (2005), Doh (2003), Tracey (2003), Mohrman \& Mohrman (1995) pointed out that strategic leadership is multifunctional, involves management of performance through strategic focus, and helps organisations cope with change that seems to be increasing exponentially in today's globalised business environment.

Copyright (C) 2013, Asian Business Consortium | ABR

\section{Discussion}

In today's highly competitive business environment, only budget oriented and forecast based planning methods are insufficient for a large corporation to survive and prosper. Firms must engage in strategic planning that clearly defines objectives and assesses both the internal and external situation to formulate strategy, implement the strategy, evaluate the progress and make adjustment as necessary to stay on track. This research tries to find how the telecom industry organisations in Bangladesh have strategic plan which helps to provide direction and focus for all employees. The focus is mostly given on finding the answer of the first research question - how does the strategic leadership role of first line managers in telecom sector organisations in Bangladesh ensure the successful implementation of performance management system?

Telecom sector organisations are totally performance oriented organisations where strategic management formulation and implementation create strategic first line managers, who successfully practice PMS, and which then gradually lead the organisations to HPWS. In the beginning level of this strategic management formulation, first line managers are helped to grow a sense to give direction to the companies with more precise and clear vision for compiling it through eloquent enough or sharing information enough to consistently articulating their visions until they become part of these organisations. Their ability to identify and articulate the business model the companies use to attend their visions. Although individual strategies can take the root for different places, the first line managers make sure that the various strategies fit together into a congruent whole and form a valid and compiling business model. Such organisational practices create strong commitment to the company's vision and business model is reflected by employees' actions and words. These first line managers are obliged to maintain secrecy in respect of all company matters and policies. They also practice empowerment and delegation as an outcome of strategic leadership. Taking vertically and horizontally expanded job duties and responsibilities with proper recognition of empowerment, first line managers in decision making process are motivated to practice better PMS. Such practices grow through emotional intelligent like self-awareness, self-regulation, motivation, empathy and social skills among the strategic leaders to lead a better PMS, satisfying the $\mathrm{P} 2$ proposition of $\mathrm{A}, \mathrm{M}, \mathrm{O}$.

The relationship of PMS and A, M, O is a function of first line managers' capacity to execute assigned tasks, motivation and willingness to perform and organisational adequacy and support to show performance. To ensure this, the surveyed telecom companies ensure their first line managers have the ability of technical 'know-how' to conduct the operation. Person 'job-fit' and 'organisation-fit' (Purcell, Kinnie, Hutchinson, Rayton \& Swart 2003) is ensured through generalised or specific strategic leadership 
development programme. These organisations also arrange more concentrated training and skill development programme, more likely a combination of the on-the-job training, job instructions, coaching and mentoring, though not generalised in nature, rather these are designed with the organisational needs to comply with regular tasks. For example, GrameenPhone, the largest telecom organisations of Bangladesh offer three months training programmes to first line managers where they are involved in real-life projects in the form of 'action learning' (S. Ahmed, per. comm. 2012). To further develop the strategic leaders, the company has introduced a culture of monitoring over employees' abilities through performance appraisal to judge their performance and achievements fairly and dispassionately. Likewise, other telecom industries like Banglalink, Airtel and Robi have been using crossutilisation and cross-training to encourage multitasking abilities among the employees. The trained strategic leaders are then given MBO (management by objectives) where their performance is again measured using a specific instrument known as KPI (key performance indicator). These strategic leaders divide their subordinates into small groups consisting of roughly 20 to 25 people with specific target to achive. For each of these groups one member is assigned as a group leader. In order to observe the overall performance of these groups, two or three meetings with the designated first line managers are usually scheduled in a month. To observe the individual group member's performance and lacking and to determine the areas of improvements, one to one meetings are held between all subordinates with their supervisors. Interestingly, GrameenPhone, to ensure performance of their employees, has adopted a 'Three Houses' approach which is consisting of 'Green House', 'Yellow House' and 'Red House'. 'Green House' is the segment where employees with good performance fall in, in 'Yellow House' segment employees with moderate performances are gathered and lastly, it is the 'Red House' where poor performers are put in (S. Ahmed, per. comm. 2012). The objective behind this 'Three Houses' approach is enabling the first line managers and employees to measure their performance which is also linked with KPI, as employees get evaluated on the basis of the achievement of $\mathrm{MBO}$ and individual targets. Performance of the employees of these 'houses' are measured in every three months period and a 'three months' performance improvement time is given to the employees who are in the yellow and red houses.

Likewise, Banglalink, Robi and Airtel, the other three organisations have always emphasised on strategic management formulation and implementation to groom up strategic leaders inside their workforce. Their HRD (human resource division) looks at the organisation's strategies and goals, and addresses the need to ensure that there is a group of effective first line managers who are capable of translating the organisation's aims into action. Organisational development initiatives are managed by taking a pragmatic approach aligned with strategic direction of the company to increase organisational capabilities and effectiveness. To select the strategic leaders for the company, the HRDs of these firms take individual / person analysis and KSA (knowledge, skill, ability) analysis through PMS. Then, from the result obtained from PMS, the HRDs arrange different employee training and development programmes. Following this process, these telecom companies develop their strategic leaders who then provides the vision, direction, purpose for growth and context for success of the firm. Then the first line managers carry and implement the strategy that is formulated by the top level managers. Action plan is then introduces among the employees and the first line managers try to make clear about the plan - how they are expected to work on the plan (J. A. Ameen, per. comm. 2012).

To find out the answer of the second research question how strategic leaders through the practice of AMO theory of performances are ensuring effective PMS in HPWSs, this research finds that in all five telecom organisations, the very first step to achieve better outcome from PMS is enriching the ability to perform task through proper and effective training sessions. The superior efficiency of all these organisations come from their ability to build strategic leaders through their strategic implementation of future leader developing initiatives. In the effort of aligning their corporate strategy to their leadership development strategy, all these organisations come up with training programmes like FLDP (future leader developing programmes) and RMT (resident management trainee programme), and also a handful of different need-basis functional, managerial and motivational trainings (R.M. Tonmoy, per, comm. 2012). Additionally, these organisations to keep their employees motivated, have linked their pay-packages successfully and meaningfully with the PMS. As a result, employees are entitled to receive competitive remuneration packages including attractive bonus, benefits and incentives, health care and insurance facilities, disability benefits, various loans and paid leaves, career progression opportunity with retirement benefits. This is how, through excellent organisational support $(\mathrm{O})$, first line managers are motivated $(\mathrm{M})$ and qualified enough (A) to deliver outstanding contributions to take the firms into HPWS. From the survey of the telecommunication companies (GrameenPhone, Robi, Banglalink and Airtel) it is also evident that the companies are maintaining a sound atmosphere necessary for the growth of employees by minimising organisational bureaucracy which is facilitated by their flat organisational structure and barriers. Moreover, to gain HPWS, in these organisations, leadership and expertise roles in the organisation, new governance model and authority matrix as per new organisational design are implemented. In addition, efficiency of work at GrameenPhone is also backed by opportunities like E-learning modules, 'Ongikaar' on ethical dilemma, overview of code of conduct, moving in $\mathrm{CHQ}$ - a new 
way of work e.g. using $\mathrm{CHQ}$ as a tool for transformation: moving mindset from 'me \& mine' to 'we \& ours', self management and knowledge sharing. All these are leading to HPWS.

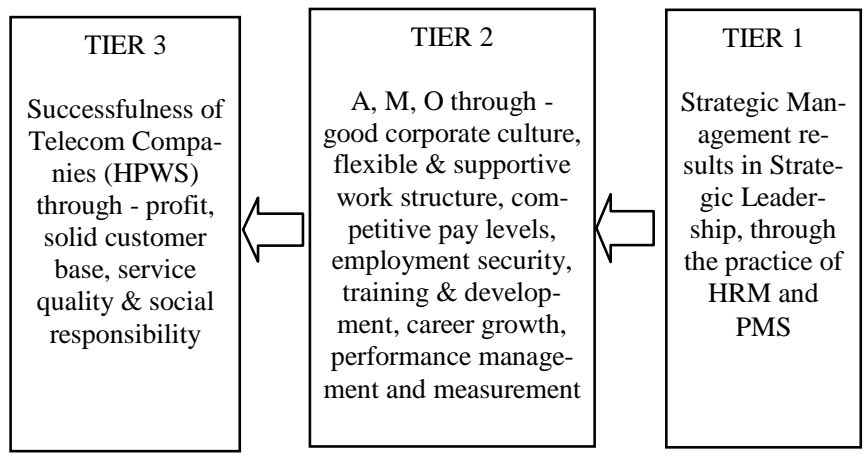

Figure 2: Hypothesised linkage of strategic leadership resulting in HPWS through $\mathrm{A}, \mathrm{M}, \mathrm{O}$

Therefore, in these telecommunication companies what is evident from the discussion so far is that if PMS is properly established then it is possible for the organisations to experience high efficiency, profit maximisation which will ultimately lead to high performance work system (HPWS), thus satisfying the $\mathrm{P} 3$ proposition.

\section{Conclusions}

The paper has argued here for three things - ability, motivation and opportunity - on which a firm needs to secure its viability. Pursuing the goals of these three inevitably involves the management of strategic tensions, including the problem of how to balance short-run needs for stable performance with long-run needs for agility. In light of these, the research finds out that telecom industries in Bangladesh have been making strategic choices of work structures, pay levels, employment security, and career opportunity that go in accordance with the preferences of most of their employees. Moreover, the paper shows importance of strategic leadership to establish an occupational environment in which personnel feel comfortable to work, giving them a sense of achievement once they reach corporate goals. Through these aspects, a leader helps the firm prevent headline risk. By working diligently and abiding by corporate policies and regulatory guidelines, rank-and-file indeed spare companies the doldrums often associated with a bad reputation. Headline risk is the possibility that a news story will negatively affect a stock's price and batter a company's image in the marketplace. Hopefully, the work will contribute enough knowledge in making other organizations of different industries HPWS and thus proper implementation of PMS.

\section{References}

A. Haque and M. Hossain, "Performance Evaluation of Bangladeshi Apparel and Textile Supply Chain Network: A Case Study," Proc. International Business Research Conf. 2011.

Copyright (C) 2013, Asian Business Consortium | ABR
A. Mohrman and S. Mohrman, "Performance Management is Running the Business," Compensation and Benefits Review, issue. July - August, pp. 6775, 1995.

A. Zafour, Human Resource Management Practices in Bangladeshi Organizations, viewed 5 March 2011, available at:

http://www.docstoc.com/docs/5544600/Human-Resource-

Management-Practices-in-Bangladeshi-Organizations-A-Case-Studyon-Bangladesh-CEntre-for-Communication-Program

A.A. Thompson and A.J. Strickland, Strategic Management: Concepts and Cases, 13th ed., New York: McGraw-Hill.

A.J. Morrison, "Developing Global Leadership Model," Human Resource Management, vol. 39, no. 2, pp. 117-131, 2000.

B.W. Tracey, Coaching Competencies and Corporate Leadership, USA: St. Lucie Press, 2003.

C. Ichniowski, T. Kochan, D. Levine, C. Olson, and G. Strauss, "What Worksat Work: Overview and Assessment," Industrial Relations, vol. 35, no. 3, pp. 299-333, 2009.

C. Jooste and B. Fourie, "The Role of Strategic Leadership in Effective Strategy Implementation: Perceptions of South African Strategic Leaders," Southern African Business Review, vol. 13, no. 3, pp.51-68, 2009.

C. Ostroff and D.E. Bowen, Moving HR to a Higher Level: HR Practices and Organizational Effectiveness, K.J. Klein and S.W.J. Kozlowski, eds., San Francisco: Jossey-Bass, 2000.

D. Elmuti, W. Minnis, and M. Abebe, "Does Education Have a Role in Developing Leadership Skills?," Management Decision, vol. 43, no. 7-8, pp. 1018-1031, 2005.

D. N. den Hartog, P. Boselie, and J. Paauwe, "Performance Management: A Model and Research Agenda," Applied Psychology: An International Review, vol. 53, no. 4, pp.556-569, 2004.

D. Renwick, "Line Manager Involvement in HRM: An Inside View," Employee Relations, vol. 25, no. 3, pp. 262-280, 2003.

D. Ulrich and W. Brockbank, The HR Value Proposition, Boston: Harvard Business School Press, 2005.

D. Ulrich, J. Zenger, and N. Smallwood, Results Based Leadership, Boston: Harvard Business School Press, 1999.

D.P. Lepak, H. Liao, Y. Chung, and E.E. Harden, “A Conceptual Review of Human Resource Management Systems in Strategic Human Resource Management Research," Research in Personnel and Human Resource Management, vol. 25, pp. 217-271, 2006.

E. Applebaum, T. Bailey, P. Berg and A. Kalleberg, Manufacturing Advantage: Why High-Performance Systems Pay Off, New York: ILR Press Ithaca, 2000.

G. Dreher and T. Dougherty, Human Resource Strategy: A Behavioural Perspective for the General Manager, Boston: McGraw-Hill Irwin, 2002.

I. Morgan and J. Rao, "Aligning Service Strategy Through Super-measure Management," Academy of Management Executives, vol. 16, no. 4, pp. 121135, 2002.

J. Collins, Good to Great, London: Random House, 2001.

J. Purcell and S. Hutchinson, "Front-line Managers as Agents in the HRM Performance Causal Chain: theory, Analysis and Evidence," Human Resource Management Journal, vol. 17, no. 1, pp. 3-20, 2007.

J. Purcell, N. Kinnie, S. Hutchinson, B. Rayton, and J. Swart, Understanding the People and PErformance Link: Unlocking the Black Box, London: Chartered Institute of Professional Development, 2003.

J. Sung and D. Ashton, High Performance Work Practices: Linking Strategy and Skills to Performance Outcomes, London: Chartered Institute of Professional Development, 2005.

J.A. Ameen, Banglalink Orascom Telecom BD Ltd. personal communication, 2012.

11 | P a g e 
J.A. Mello, Strategic Human Resource Management, India: Cengage Learning, 2011.

J.A. Pearce and R.B. Robinson, Formulation, Implementation and Control of Competitive Strategy, 9th ed., Boston: McGraw-Hill Irwin, 2007.

J.P. Campbell, R. McCloy, S. Oppler, and C. Sager, A Theory of Performance: Personnel Selection in Organisations, San Francisco: Jossey-Bass, 1993.

J.P. Doh, "Can Leadership Be Taught? Perspective from Management Educators," Academy of Management Learning and Education, vol. 2, no. 1, pp. 54 67, 2003.

J.P. MacDuffie, “Human Resource Bundles and Manufacturing Performance: Organizational Logic and Flexible Production Systems in the World Auto Industry," Industrial and Labor Relations Review, vol. 48, no. 2, pp. 197221, 1995.

J.R. Detert and E.R. Burris, "Leadership Behavior and Employee Voice: Is the Door Really Open?," Academy of Management Journal, vol. 50, no. 4, pp.556-569, 2007.

L. Bossidy and R. Charan, Execution: The Discipline of Getting Things Done, London: Random House, 2002.

L. Gratton, V. Hope-Hailey, P. Stiles, and C. Truss, "Linking Individual Performance to Business Strategy: The People Process Model," Human Resource Management, vol. 38, no. 1, pp. 17-31, 1999.

L. Hall and D. Torrington, Letting Go or Holding On - The Devolution of Operational Personnel Activities," Human Resource Management Journal, vol. 8, no. 1, pp. 41-55, 1998.

L.D. Alexander, "Successfully Implementing Strategic Decisions," Long Range Planning, vol. 18, no. 3, pp. 91-97, 1985.

L.G. Hrebiniak, Making Strategy Work: Leading Effective Execution and Change, New Jersey: Wharton School Publishing, 2005.

M. Armstrong and A. Baron, "Reward Strategies and Trends in the UK: The Land of Diverse and Pragmatic Dreams," Compensation Benefits Review, vol. 37, no. 4, pp.41-53, 2005.

M. Beer, and R.A. Eisenstat, "The Six Silent Killers of Strategy Implementation", Sloan Management Review, vol. Summer, no. 29, 2000.

M. F. Chowdhury, "Performance Management Practices in Organizations Operation in Bangladesh: A Deeper Examination," World Review of Business Research, vol. 1, no. 2, pp.153-167, 2011.

M. Freedman and B.B. Tregoe, The Art and Discipline of Strategic Leadership, New York: McGraw-Hill, 2003.

M. Mahmood, "Strategy, Structure and HRM Practices in Multinational Subsidiaries: European MNCs in a Developing Country Context," Proc. International Business Research Conf. 2010.

M.A. Huselid, "The Impact of Human Resource Management Practices on Turnover, Productivity and Corporate financial Performance," Academy of Management Journal, vol. 38, pp. 635-672, 1995.

M.F. Chowdhury, "Bleak House or Bright Future?: Performance Management in Bangladeshi Organizations," Proc. Asia-Pacific Business Research Conf. 2011.

N. Heraty and M. Morley, "Line Managers and Human Resource Development," Journal of European Industrial Training, vol. 19, no. 10, pp. 31-37, 1995.

N. Kinnie, S. Hutchinson, J. Purcess, B. Rayton, and J. Swart, "Satisfaction with HR Practices and Commitment to the Organisation: Why Only Size Does Not Fit All," Human Resource Management Journal, vol. 15, no. 4, pp. 9-29. 2005.

P. Boxall and J. Purcell, Strategy and Human Resource Management: Management, Work and Organisations. New York: Palgrave Macmillan, 2003.

P. McGovern, L. Gratton, V. Hope-Hailey, and C. Truss, "Human Resource Management on the Line," Human Resource Management Journal, vol. 7, no. 4, pp. 12-29, 1997.

Copyright (C) 2013, Asian Business Consortium | ABR
P.M. Wright and L.H. Nishii, Strategic HRM and Organizational Behavior: Integrating Multiple Levels of Analysis, New York: Cornell University Press, 2006.

P.M. Wright, L.M. Gardner, and L.M. Moynihan, "The Impact of HR Practices on the Performance of Business," Human Resource Management Journal, vol. 13, pp. 21-36, 2003.

R.A. Noe, Employee Training and Development, New York: McGraw-Hill, Irwin, 2007.

R.L. Lynch, Corporate Strategy, London: Pitman, 2006.

R.M. Tonmoy, GrameenPhone Ltd.personal communication, 2012.

R.S. Kaplan and D.P. Norton, Strategy Maps: Turning Intangible Assets into Tangible Results, Boston: Harvard Business School Press, 2004.

R.S. Kaplan and D.P. Norton, The Strategy Focused Organisation: How Balanced Scorecard Companies thrive in the New Business Environment, Boston: Harvard Business School Press, 2004.

S. Ahmed, GrameenPhone Ltd. personal communication, 2012.

S. Gilmore and S. Williams, Human Resource Management, New York: Oxford University Press, 2011.

S. Hutchinson and J. Purcell, "Managing Ward Managers for Roles in HRM in the NHS: Overworked and Under-resourced," Human Resource Management Journal, vol. 20, no. 4, pp. 357-374, 2010.

S. Hutchinson and J. Purcell, Bringing Policies to Life: The Vital Role of Front Line Managers in People Management, London: Chartered Institute of Personnel and Development, 2003.

S.E. Khilji and X. Wang, "Intended and Implemented HRM: The Missing Linchpin in Strategic Human Resource Management Research," International Journal of Human Resource Management, vol. 17, no. 1, pp. 1171-1189, 2006.

T.G. Gutteridge, Z.B. Leibowitz, and J.E. Shore, "A New Look at Organizational Career Development," Human Resource Planning, vol. 16, no. 2, pp. 71-84, 1993

$$
--0--
$$

